$1-1-1954$

\title{
A general-purpose garden pesticide
}

C. K. Dorsey

M.E. Gallegly

Follow this and additional works at: https://researchrepository.wvu.edu/ wv_agricultural_and_forestry_experiment_station_bulletins

\section{Digital Commons Citation}

Dorsey, C. K. and Gallegly, M. E., "A general-purpose garden pesticide" (1954). West Virginia Agricultural and Forestry Experiment Station Bulletins. 365T.

https://researchrepository.wvu.edu/wv_agricultural_and_forestry_experiment_station_bulletins/630 @ WVU. It has been accepted for inclusion in West Virginia Agricultural and Forestry Experiment Station Bulletins by an authorized administrator of The Research Repository @ WVU. For more information, please contact ian.harmon@mail.wvu.edu. 
ST

Q1 $11, y^{2}=$

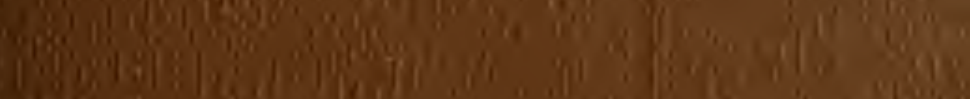

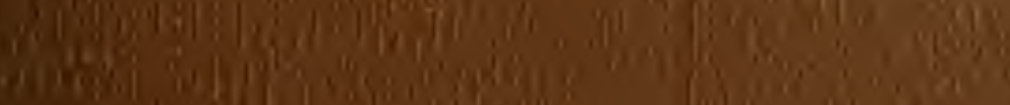
(1)

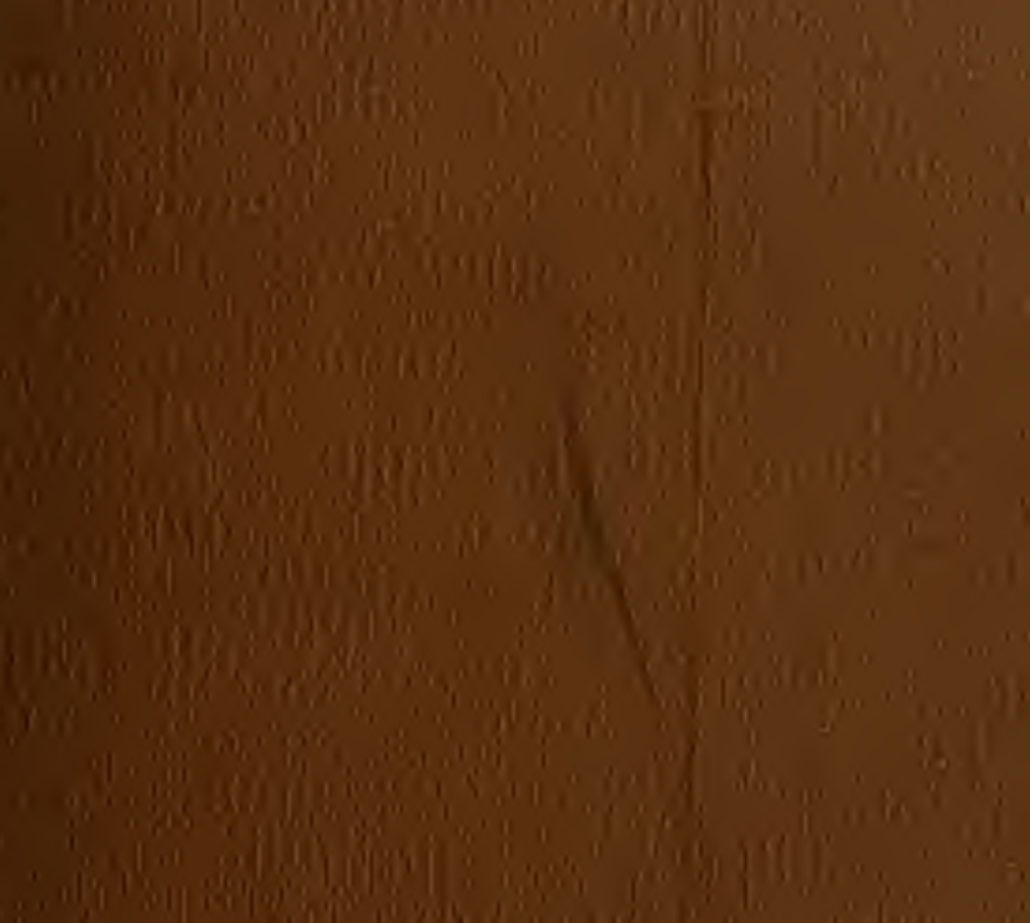
als

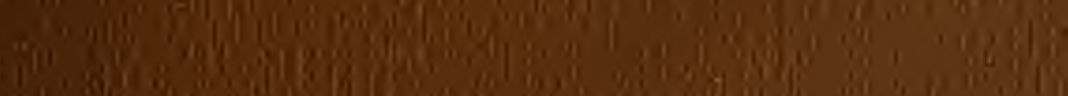
39. (1) (1)

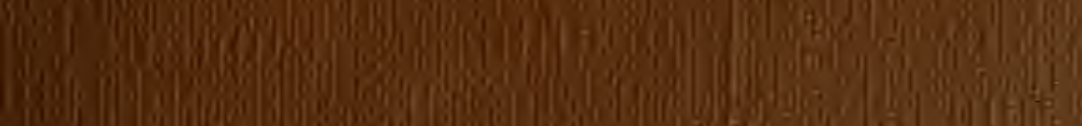

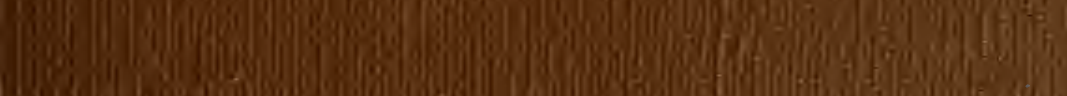

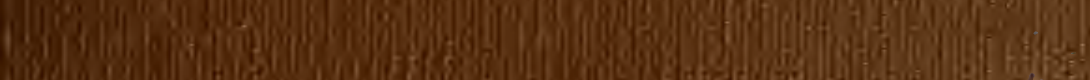





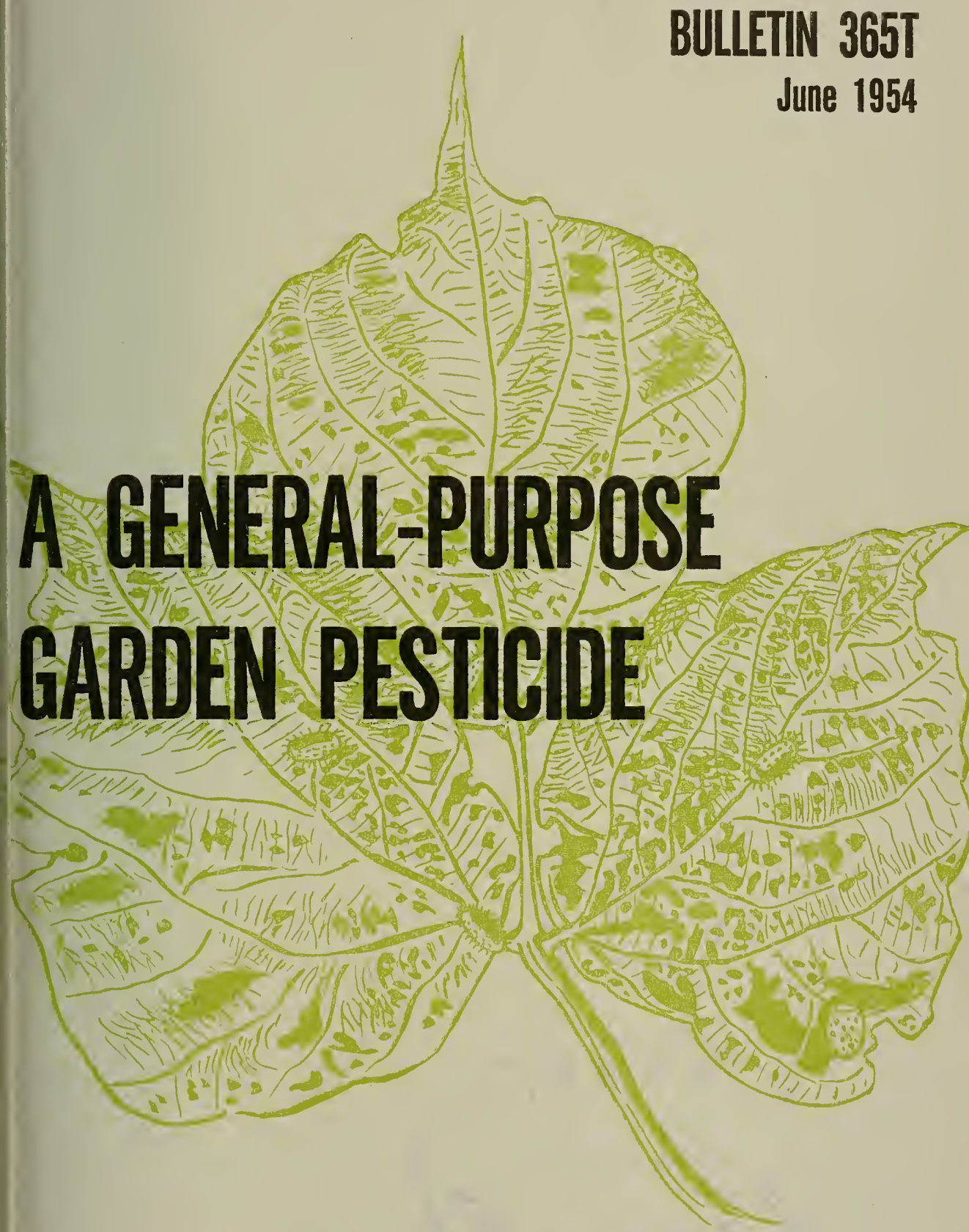




\section{AUTHORS}

Authors of $A$ General-Purpose Garden Pesticide are C. K. DORSEY, Entomologist and Professor of Entomology, and M. E. GALLEGLY, Assistant Plant Pathologist and Assistant Professor of Plant Pathology.

\section{ACKNOWLEDGEMENT}

The authors are indebted to Kemper $\mathrm{L}$. Callahan for assistance in portions of the studies.

WeSt ViRgINIA UNIVERSITY Agricultural EXPERIMENT Station

College of Agriculture, Forestry, and Home Economics

H. R. VARNEY, DIRECTOR MORGANTOWN 


\section{A General-Purpose Garden Pesticide}

\section{K. DORSEY and M. E. GALLEGLY}

$\mathrm{N}$ recent years numerous new insecticides and fungicides have been 1 developed and many have been recommended for use in the home garden. These vary considerably in their effectiveness in the control of different pests. For example, rotenone is effective in controlling the Mexican bean beetle and the potato flea beetle, but is ineffective against the potato leafhopper. DDT is effective in controlling the leafhopper and the potato flea bettle, but is of little value in controlling the bean beetle. Similar differences in fungicidal control of plant diseases would make it necessary for the home gardener to use many insecticides and fungicides if he uses the most effective material for each of the pests likely to attack his garden crops. Moreover, the average gardener is not sufficiently well informed on the nature of various pests and requirements for pest control to enable him to use all the available materials effectively. In addition to the added cost of many pesticides, there also is the necessary nuisance of emptying the sprayer or duster when a different material is needed for some specific pest. Development and introduction of new materials causes the situation to become more complex, and experience shows that many gardeners use the wrong materials or apply them at the wrong times with disappointing results.

This situation has created a demand for a single formulation of insecticides and fungicides that would be reasonably effective in control of most common garden pests. If available, such a formulation would greatly facilitate control of garden pests. The gardener could purchase a single preparation and apply it to all crops in his garclen at recommended intervals with reasonable assurance that the most important pests would be controlled. This would greatly simplify and increase the effectiveness of garden pest control.

The principal objection to the use of such a formulation is that there would be an econonic waste in that some ingredients would be used when they were not needed and that there would be a corresponding increase in cost per pound of the formulation. This is not necessarily true. Practical experience has shown there is usually a comparable amount of waste by misapplication when the different ingredients are applied separately by the average home gardener, and that there is 
usually more waste when several different preparations are used. The same amount of active ingredients would cost less in one formulation because of the decreased cost of diluents and packaging.

Another objection is that all garden plants are not equally tolerant to the different insecticides and fungicides and that some plants might be injured by a general-purpose formulation. It is believed that this objection has been over-emphasized, because during several years of experimentation in West Virginia no appreciable plant injury has been observed except in a few cases when copper was applied too heavily.

In vicw of this need for a general-purpose pesticide formulation, the West Virginia University Agricultural Experiment Station began experiments in 1947 with the materials then available. On the basis of a single year's experiment, in which representative garden crops were used, a multiple-purpose dust containing copper, rotenone, and DDT was recommended (4). It was recognized at that time that discovery of new insecticides and fungicides would require further experiments to determine the most satisfactory formulation.

With the appearance of zineb as a promising substitute for copper, and methoxychlor and lindane as insecticides more versatile than DDT, further experiments seemed desirable. In 1950 another series of experiments was made to compare various combinations of zineb, copper, methoxychlor, and lindane for the control of representative types of garden pests. On the basis of these experiments (2), it was concluded that "A completely satisfactory 'all-purpose' garden dust is not yet practical because of the absence of a suitable aphicide." A mixture of zineb and methoxychlor was recommended as the most satisfactory formulation, although it was recognized that this mixture did not control bean beetle as well as rotenone. However, since reasonably good control of this insect was obtained when the mixture was used properly, it was recommended as the best "all-purpose" formulation then available. This formulation was widely used with general satisfaction, in spite of its shortcomings.

In 1952, when the insecticide malathion became available, additional tests were initiated to develop an improved general-purpose garden pesticide. Malathion was reported to have a wide range of effectiveness against pests inchuding aphids, Mexican bean beetle, and mites. It was desired, therefore, to compare malathion with other insecticides in several possible general-purpose formulations. These tests were conducted with spray formulations in 1952 and with both spray and dust formulations in 1953. Zineb was the only fungicide used in the 1952 experiments, while the newer fungicides maneb and captan were compared with zineb in the 1953 tests. Results of the 1952 and 1953 experiments are reported in this bulletin. 


\section{Methods and Materials}

The experimental gardens were planned so that each plot contained one row, 30 feet long, of each of the garden vegetables used. There were four randomized and replicated plots for each spray or dust treatment. The plots were separated by alleys nine and ten feet wide to facilitate spraying operations.

In 1952 vegetables planted were potato, tomato, bean, cucumber, and cabbage. The potato seed pieces were planted ten inches apart; tomatoes were set three feet apart; bean plants were spaced at six-inch intervals; cucumbers were planted in hills three feet apart, and cabbage plants were set eighteen inches apart. Varieties and planting dates for these vegetables were: Katahdin potato, May 2; Stoke's Cross \#1 tomato, June 4; Burpee's Tendergreen bean, May 15; Burpee Hybrid cucumber, May 15; and Jersey Wakefield cabbage, May 2. To facilitate spraying operations and recording of data, the vegetables were planted in rows six feet apart, from left to right in the order given above.

In 1953 the experiments included nine vegetable crops. Each plot contained twelve rows, three feet apart. The rows of tomatoes and cucumbers were planted so that there were vacant rows paralleling each side; the sweet corn was planted in double rows. The other crops were planted in single rows, three feet apart. The distance between plants in the row were the same as in 1952 for potato, tomato, green bean, cucumber, and cabbage. Six-weeks old head lettuce plants were set eighteen inches apart; onion sets were planted six inches apart; lima beans were spaced at six inches, and the sweet corn was thinned to approximately one foot between plants. The Burpee Big Boy hybrid tomatoes were set in the field two weeks later than normal for the Tygart Valley area. Varieties and planting dates for the crops used in 1953 follow: Pontiac potato, May 1; Ebenezer onion, May 5; Great Lakes head lettuce, May 12; Marion Market cabbage, May 12; Fordhook 242 lima bean, June 3; Golden Cross Bantam sweet corn, June 3; Burpee Hybrid cucumber, June 3; Burpee Big Boy tomato, June 17; Topcrop green bean, June 3.

The experiments were carried out in the Tygart Valley near Huttonsville, West Virginia. The 1953 plots were in a different location from the 1952 plots, but on the same farm. The soil, a clay loam, was fertilized each year with a 5-10-10 mixume at the rate of 1,400 pounds per acre. Clean cultivation practices were followed.

Fungicides used were zineb (65\%, wettable powder), maneb $(70 \%$ wcttable powder), and captan (50\% wettable powder). Insecticides used were DDT $(25 \%$ and $50 \%$ wettable powder $)$, methoxychlor $(50 \%$ wettable powder), malathion (25\% wettable powder), and rotenonc ( $4 \%$ wettable powder). In 1952 the pesticide combinations werc applied as 
sprays, and in 1953 they were applied both as sprays and dusts. Since the 1952 experiments were designed to determine the best combinations for insect control, zineb was usect in all treatments. In 1953, however, all three fungicides were used. The nature and concentration of the different insecticide-fungicide combinations used in the studies are given in Tables 1, 2 and 3. Since the zineb-methoxychlor-malathion and zinebDDT-malathion combinations gave the best results in 1952, they were selected as basic formulations for the 1953 experiments.

The plots were sprayed or clusted at weekly intervals beginning the second week in June and continuing until the second week in September. The spray mixtures were applied at 250 pounds pressure at the approximate average rate of 150 gallons per acre. In 1952 the materials were applied with a single nozzle (number 3 disc) hand gun, and in 1953 a three-nozzle (central and two lateral nozzles) single row boom-type gun was used. The dust mixtures were applied with a rotary hand duster at the approximate average rate of 40 pounds per acre. Dust applications were usually made during the late afternoon when there was little air movement.

Methods of insect population counts and damage surveys on the crops varied according to the insect and host involved. For measuring injury by the potato flea beetle, Epitrix cucumeris (Harris), three terminal leaflets from the second leaf below the growing point were collected from ten different plants at intervals of three feet along the row. They were transported to the laboratory, and the total holes and points of feeding were counted by the use of transmitted light from a bacterial colony counter. The results were converted to the average number of holes per leaflet. Two counts were made, the first after the emergence of the first generation and the second after the emergence of the second generation of beetles.

Population estimates of the potato leafhopper, Empoasca fabae (Harris), were made in 1952 by counting the leaves that shower typical hopper-burn injury on the first five hills in each replicate. In 1953 the leaflets collected for flea-beetle injury counts were also examined for leafhopper injury. The number of leaves showing typical leafhopper injuries were converted to percentages.

The incidence of bacterial wilt (Erwinia tracheiphila) was used as an indication of the abundance of striped, Acalymma vittata (Fab.), and spotted, Diabrotica undecimpunctata howardi Barb., cucumber beetles. The wilted plants were counted at intervals throughout the summer. Results were then converted to percentages of wilted plants.

In 1952 population counts of Mexican bean beetle, Epilachna varivestis Mulsant, were made of both the adults and larvae. To evaluate 


\section{Table 1. Combinations and Concentrations of Pesticides Used IN THE 1952 SPRAY EXPERIMENTS}

\begin{tabular}{|c|c|c|}
\hline $\begin{array}{l}\text { MIXTURE } \\
\text { NUMBER }\end{array}$ & INGREDIENTS & $\begin{array}{l}\text { COnCentration } \\
\text { IN POUNDS } \\
\text { PER } 100 \text { Gallons }\end{array}$ \\
\hline $\begin{array}{l}1 \\
2 \\
3 \\
4 \\
5 \\
6 \\
7 \\
8\end{array}$ & $\begin{array}{l}\text { Zineb (Zin.) plus methoxychlor (meth.)* } \\
\text { Zin. plus DDT** } \\
\text { Zin. plus rotenone (rote.) } \\
\text { Zin. plus malatbion (mala.) } \\
\text { Zin. plus meth. plus mala. } \\
\text { Zin. plus DDT plus mala. } \\
\text { Zin. plus rote. plus mala. } \\
\text { Zin. }\end{array}$ & $\begin{array}{l}2.5-2 \\
2.5-4 \\
2.5-4 \\
2.5-2 \\
2.5-2-2 \\
2.5-4-2 \\
2.5-4-2 \\
2.5\end{array}$ \\
\hline
\end{tabular}

* The abbreviations given in parentheses following each pesticide name are used in the following tables and text.

**A 25 per cent wettable DDT powder was used.

Table 2. Pesticide Combinations and Concentrations Used in the 1953 SPRAY TESTS

\begin{tabular}{|c|c|c|}
\hline $\begin{array}{l}\text { Mixture } \\
\text { Number }\end{array}$ & INGREDTENTS* & $\begin{array}{c}\text { CONCENTRATION** } \\
\text { IN POUNDS } \\
\text { PER } 100 \text { GaLLONS }\end{array}$ \\
\hline $\begin{array}{r}1 \\
2 \\
3 \\
4 \\
5 \\
6 \\
7 \\
8 \\
9 \\
10\end{array}$ & $\begin{array}{l}\text { Zin. plus meth. plus mala. } \\
\text { Zin. plus DDTt plus mala. } \\
\text { Zin. plus mala. } \\
\text { Maneb (man.) plus metb. plus mala. } \\
\text { Man. plus DDT plus mala. } \\
\text { Captau (cap.) plus meth. plus mala. } \\
\text { Cap. plus DDT plus mala. } \\
\text { Meth. plus mala. } \\
\text { Zin. } \\
\text { Control (No Spray) }\end{array}$ & $\begin{array}{r}2-2-21 / 2 \\
2-2-21 / 2 \\
2-21 / 2 \\
2-2-21 \frac{1}{2} \\
2-2-21 / 2 \\
2-2-21 \frac{2}{2} \\
2-2-21 / 2 \\
2-21 / 2 \\
2\end{array}$ \\
\hline
\end{tabular}

*A bousehold detergent (Dreft) was used at the rate of one level tablespoon per 10 gallons of water in all spray mixtures.

**The concentration of zineb was Iowered from $2 \frac{1}{2}$ to 2 pounds, while that of malathion was increased from 2 to $2 \frac{1}{2}$ pounds in 1953.

A 50 per cent wettable DDT powder was used in the 1953 experiments.

\section{Tabie 3. Combination and Concentration of Pesticides Used IN THE 1953 IUUST EXPERIMENTS}

\begin{tabular}{|c|c|c|c|}
\hline $\begin{array}{l}\text { MiXTURE } \\
\text { NUMBER }\end{array}$ & ACTIVE INGREDIENTS & $\begin{array}{c}\text { PER CENT } \\
\text { ACTIVE } \\
\text { INGREDIENTS }\end{array}$ & DILUENT \\
\hline $\begin{array}{l}1 \\
2 \\
3 \\
4 \\
5 \\
6\end{array}$ & $\begin{array}{l}\text { Zin. plus meth. plus mala. } \\
\text { Zin. plus DDT plus mala. } \\
\text { Zin. plus mala. } \\
\text { Zin. plus meth. plus mala. } \\
\text { Zin. plus meth. plus mala. } \\
\text { Control (No Treatment) }\end{array}$ & $\begin{array}{l}6.5-5-4 \\
6.5-5-4 \\
6.5-4 \\
3.9-5-4 \\
6.5-5-4\end{array}$ & $\begin{array}{l}\text { Pyrophyllite } \\
\text { Pyrophyllite } \\
\text { Pyrophyllite } \\
\text { Pyrophyllite } \\
\text { Attaclay }\end{array}$ \\
\hline
\end{tabular}


adult injury, 30 leaflets collected at random from the row were removed from the plant and the feeding points were counted. These first counts were made before the eggs hatched. To evaluate the larval population, total specimen counts were made on each row. In 1953, counts of adults, larvae, and egg masses were made from ten plants located at intervals of three feet along the row; the counts were converted to number of each stage per plant.

Counts of the aphid, Macrosiphnm solanifolii (Ashmead) on tomatoes were made from 210 leaflets from each replicate (three sets of seven terminal leaflets per plant). Aphid counts in 1952 on cucumber were made from twenty leaves from each replicate. Aphid counts were not made in 1953 since these insects were not present in sufficient numbers.

The two-spotted mite, Tetranychus bimaculatus Harvey, caused injury on beans and cucumbers in 1952. Two-spotted mite injury on cucumber was determined by counting all the mites per square inch of leaf surface on 200 leaves from each row. Mite counts were not made in 1953 because of extremely light infestation.

In 1952 injury caused by the imported cabbage worm, Pieris rapae (L.), was determined by counting the holes present at harvest time in the leaves from the twenty heads in each row. In 1953 imported cabbage worms and cabbage loopers, Trichoplusia ni (Hbn.) on five plants at 3-foot intervals in the row were counted and the mean number per plant was computed.

Percentage defoliation was determined (3) from potato and tomato plots to measure the combined effects of early blight (Alternaria solani), late blight (Phytophthora infestans), potato flea-beetle injury, and potato leafhopper injury. The amount of tomato fruit rot was recorded at each harvest, and the total fruit rot percentage determined.

Although Golden Cross Bantam sweet corn is resistant to bacterial wilt (Bacterinm stewartii), some wilt developed in the young seedlings. Also, considerable necrosis of leaves was noted on mature plants as a combined action of the corn flea beetle, Chaetocnema pulicaria Welsh., and the resistant reaction of the foliage to the wilt pathogen. On this basis the percentages of wilted plants and of leaf necrosis were determined. In determining the percentage of leaf necrosis, the terminal eight inches of ten leaves collected at 3-foot intervals from the base of the lowest ear were examined and the percentage of necrosis recorded after the method of Horsfall and Barratt (3).

In rating cucumber foliage for severity of anthracnose (Colletotrichum lagenarium) a disease index of from 1 to 4 was established. Vines showing no anthracnose were placed in class 1 ; those showing but a few lesions were placed in class 2; those with a large number of 
lesions in class 3; and those with leaves necrotic and dying due to a coalescing of lesions were placed in class 4 . The readings from the individual vines were averaged to determine an index for the entire row.

Tomatoes, beans, and cucumbers were harvested several times weekly and the weights in pounds per plot were recorded. At the end of harvest the weights were totaled and converted to tons per acre. The cabbage heads were harvested when mature and their weights were totaled and converted to tons per acre. The lettuce heads were harvested when mature and yield recorded as mean weight per head and mean number of heads per plot. Sweet corn ears were harvested when mature and their mean weights per plot were converted to tons per acre. The potatoes were dug and graded and the total yields and yields of U.S. No. 1 tubers were converted to bushels per acre. Because of poor growth and uneven stand, onion yield was not measured. All yield data, insect population counts, estimates of damage and disease data were subjected to analysis of variance.

\section{Experimental Results}

\section{EXPERIMENTS}

Potato (Tables 4 and 5)-Leafhoppers and flea beetles were controlled best by spray mixtures containing either DDT or methoxychlor. Though Turner and Woodruff (5) observed that DDT gave better control of flea beetles than did methoxychlor, no difference was observed in the West Virginia experiments. Rotenone gave adequate control of flea beetles, but control was not equivalent to that given by DDT or methoxychlor; rotenone gave no control of leafhoppers. Malathion gave partial control of leafhoppers, but no control of flea beetles. The addition of malathion to mixtures containing either DDT, methoxychlor, or rotenone, neither improved nor impaired their efficiency in fleabeetle and leafhopper control. The plots sprayed with a mixture containing methoxychlor and malathion gave highest yield, but this was not significantly higher than that from the control plot.

Tomato (Tables 4 and 5)-Spray mixtures containing malathion or rotenone gave satisfactory control of aphicls on tomato. DDT and methoxychlor sprays gave no control of aphids; in fact, the aphid populations were twice that of the control plot, probably due to the fact that the number of predators ${ }^{1}$ was reduced by these insecticides.

1Larvae of Diptera (Syrphidae) and Coleoptera (Coccinellidae). 


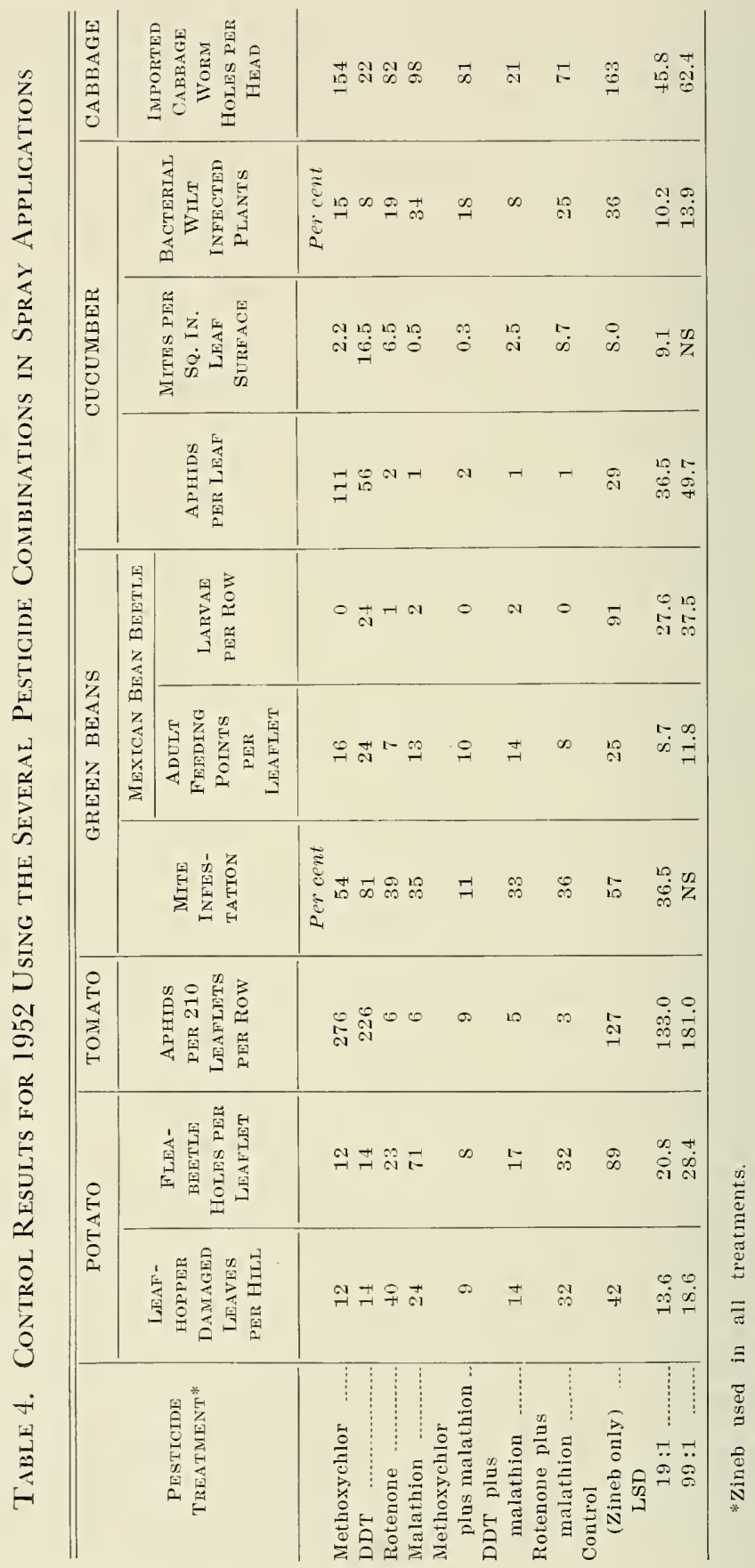


Table 5. Yields of Garden Crops in 1952 Sprayed With Different Pesticide Mixtures

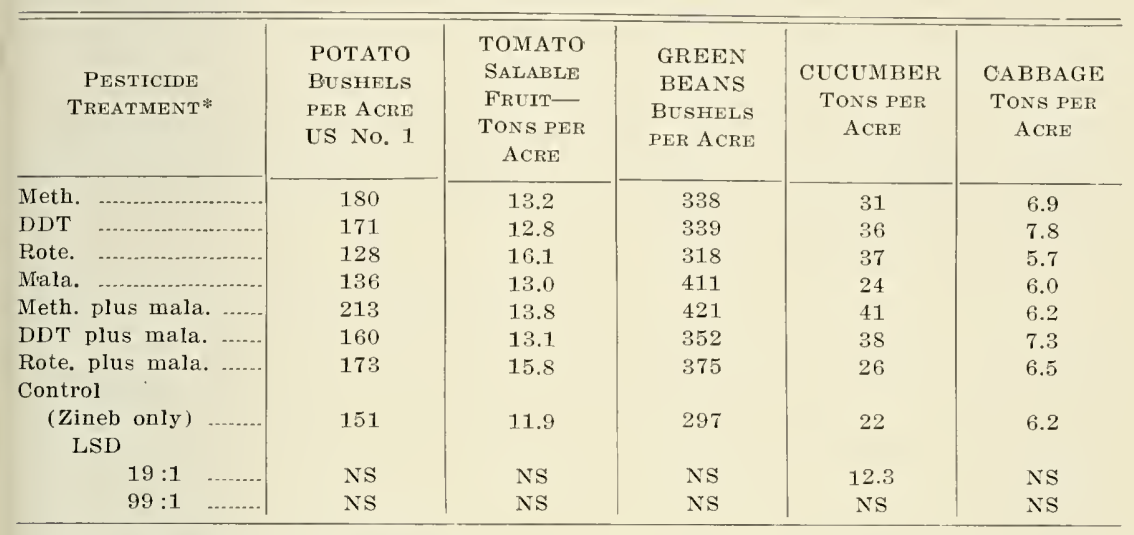

*Zineb used in all treatments.

Although differences in the yield data were non-significant, highest yields of tomatoes were obtained from plots sprayed with zineb-rotenone or zineb-rotenone plus malathion mixtures.

Green Bean (Tables 4 and 5)-The Mexican bean beetle was effectively controlled by rotenone and by malathion. Best control resulted from the use of rotenone or a rotenone-malathion mixture. The mixture containing methoxychlor and malathion gave a degree of control equal to that of rotenone. Neither methoxychlor nor DDT were effective in killing the adult Mexican bean beetle; however, the larvae were killed by methoxychlor, rotenone, and malathion. DDT, when used alone, reduced the larval populations, but control was significantly poorer than that resulting from the use of the other three insecticides. Some control of the two-spotted mite was given by rotenone and malathion, but except for that given by the zineb-methoxychlor-malathion mixture the mite population differences were non-significant when compared with the population on the control plots. The highest yield of green beans was obtained from plots sprayed with the zineb-nethoxychlor-malathion mixture.

Curumber (Tables 4 and 5)-Mitc infestations on cucumber plants were satisfactorily controlled by sprays containing zincl)-malathion or zineb-malathion-methoxychlor. The mite populations on the plots sprayed with zineb-DDT were wice that of the control. Control of the aphid, Aphis gossypii Glover, on cucmmber was excellent when plots were sprayed with zincb-rotenone, zinch-malathion, or mixtmes containing one of these insecticides. The aphid populations on plots sprayed 
with zineb-DDT or zineb-methoxychlor alone were from two to four times as great as those on the control plots. Control of the cucumber beetles, as evidenced by the incidence of bacterial wilt, was best in plots sprayed with zineb-DDT or zineb-DDT-malathion. Methoxychlor and rotenone sprays gave fair control of bacterial wilt, and malathion alone gave no control. Highest yields were obtained from plots sprayed with the zinebmethoxychlor-malathion mixture. The zineb-rotenone, zineb-DDT and zineb-DDT-malathion sprayed plots also gave yields significantly higher than those of the check plots.

Cabbage (Tables 4 and 5)-The imported cabbage worm was the only insect pest on cabbage abundant enough to warrant damage estimates. Zineb-DDT or zineb-DDT in combination with malathion gave best control. The sprays containing rotenone, malathion, methoxychlormalathion, or rotenone-malathion gave only fair control when compared with that given by DDT. Because of the waxy nature of cabbage leaves, a spreader is needed to obtain best control with these materials; in the 1952 experiments none was used. The yield differences between treatments were not significant; although plots sprayed with zineb-DDT or zineb-DDT-malathion produced highest yields.

Summary of the 1952 results-To obtain a measure of the over-all effectiveness, the different pesticide combinations were ranked from 1 to 4 (best to poorest), based on their performance on each of the five vegetable crops. To obtain the insect control rank on a given crop, the control of each species of pest and yield of the crop were evaluated separately and their sums were used to determine the performance rank of each pesticide combination on that crop. The summary of the ranks of the pesticides on the five crops, given in Table 6, shows that the zineb-

\section{Table 6. Summary of the Effectiveness of Different Pesticide Combinations Used in 1952}

\begin{tabular}{|c|c|c|c|c|c|c|}
\hline \multirow{2}{*}{$\begin{array}{l}\text { PESTICIDE* } \\
\text { TREATMENT }\end{array}$} & \multicolumn{5}{|c|}{ RANK OF EFFECTIVENESS } & \multirow{2}{*}{$\begin{array}{l}\text { SUMMARY } \\
\text { OF RANKS }\end{array}$} \\
\hline & Potato & TOMATO & BEAN & CUCUMBER & CABBAGE & \\
\hline Methoxychlor & 2 & 4 & 3 & 3 & 3 & 15 \\
\hline DDT & 2 & 3 & 4 & 3 & 1 & 13 \\
\hline Rotenone ............. & 4 & 1 & 2 & 2 & 3 & 12 \\
\hline Malathion & 4 & 2 & 2 & 3 & 4 & 15 \\
\hline $\begin{array}{l}\text { Methoxychlor } \\
\text { plus malathion }\end{array}$ & 1 & 2 & 1 & 1 & 2 & 7 \\
\hline $\begin{array}{l}\text { DDT plus } \\
\text { malathion }\end{array}$ & 2 & 2 & 2 & 1 & 1 & 8 \\
\hline $\begin{array}{l}\text { Rotenone plus } \\
\text { malathion }\end{array}$ & 3 & 1 & 1 & 3 & 2 & 10 \\
\hline $\begin{array}{l}\text { Zineb (No } \\
\text { insecticide }\end{array}$ & 4 & 3 & 4 & 4 & 4 & 19 \\
\hline
\end{tabular}

* Zineb was used in combination with all insecticide mixtures. 
methoxychlor-malathion and zineb-DDT-malathion combinations gave the best results in 1952 .

\section{Results}

The results of the 1953 experiments are divided into two partsresults from the spray trials and those from the clust trials. The data from these experiments have been condensed into six tables. Tables $7,8,9$, and 10 show the effect of the spray and clust combinations in control of insect and diseases prevalent on the nine crops; Tables 11 and 12 present yields of the crops.

Potato-Spray mixtures containing either methoxychlor or DDT gave good control of the potato flea beetle and leafhopper. Slight, but unsatisfactory, control was obtained when malathın alone was used as the insecticide. Leafhoppers were controlled a little better by mixtures containing methoxychlor than by those containing DDT. Defoliation due to the combined effects of early blight, late blight, flea-beetle injury, and leafhopper injury was effectively controlled by the zineb-methoxychlor-malathion, zineb-DDT-malathion, maneb-methoxychlor-malathion, and maneb-DDT-malathion mixtures. Early blight control was reduced when captan was used as the fungicide. Defoliation was greater when the insecticide was omitted from the mixture than it was when the fungicide was omitted, indicating that in 1953, insects were more destructive on potatoes than were diseases. The highest yield of potatoes was from the zineb-methoxychlor-malathion spray plot; there was no significant difference, however, in this yield and that from the zinebDDT-malathion, maneb-methoxychlor-malathion, maneb-DDT-malathion, captan-methoxychlor-malathion, and captan-DDT-malathion sprayed plots. Yields were reduced when either the fungicide, insecticicle, or both were omitted.

Good control of flea beetles, leafhoppers, and defoliation was also obtained in the dust experiments from the zineb-methoxychlor-malathion and zineb-DDT-malathion mixtures. A decrease in leafhopper control and a consequent decrease in defoliation control occurred when the zincb-nalathion dust mixture (without methoxychlor) was used. The reduction of zineb concentration from 6.5 to 3.9 per cent did not reduce the efficiency of the zineb-methoxychlormalathion dust on potatoes; in fact, highest yields were obtained from plots treated with this mixture. A slight reduction in flea-beetle control and yield was observed when attaclay was used as a diluent in place of pyrophyllite.

Tomato-There were no serious insect pests in the tomato plots in 1953; even those commonly found on tomato plants were not present 


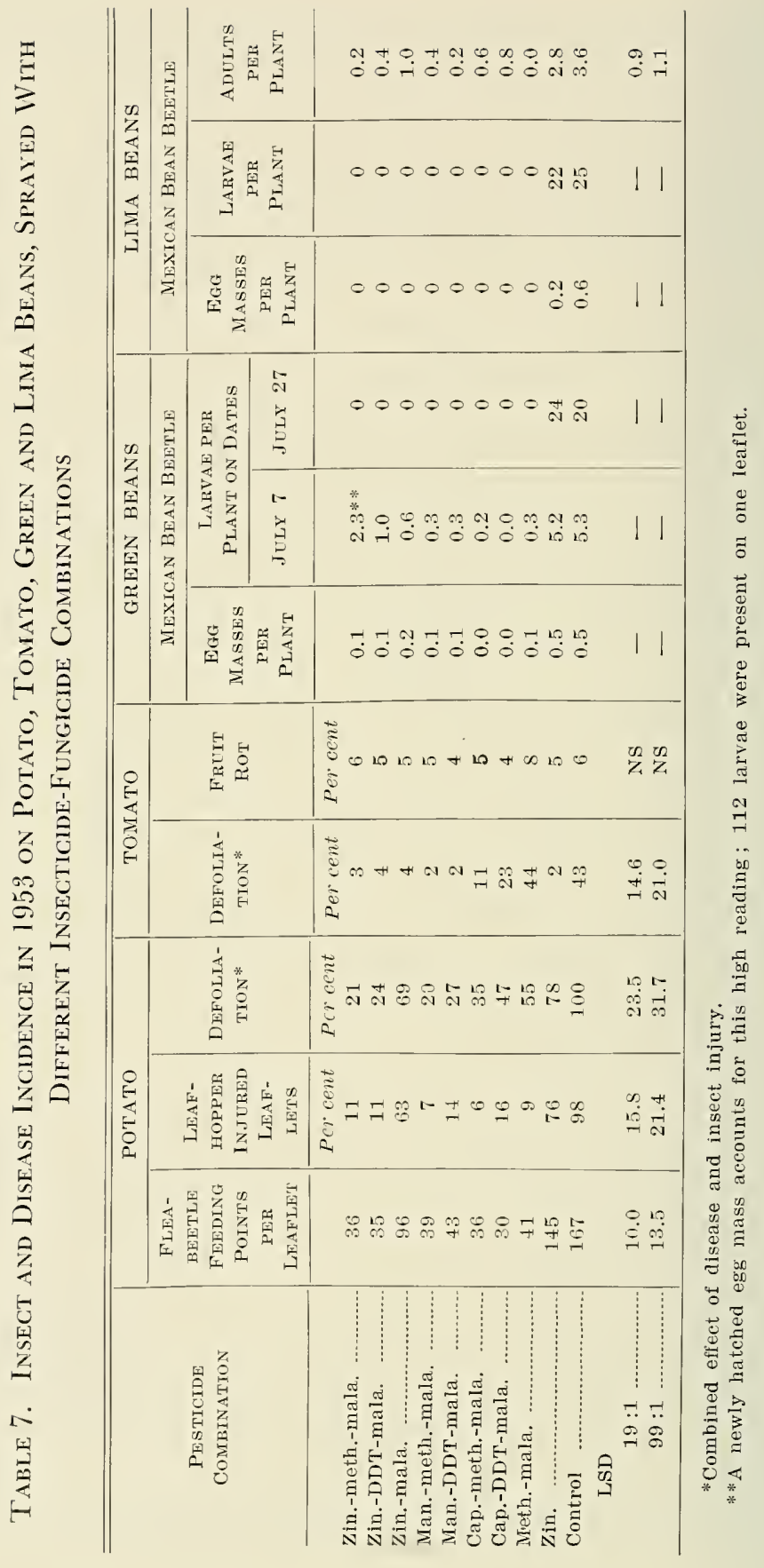




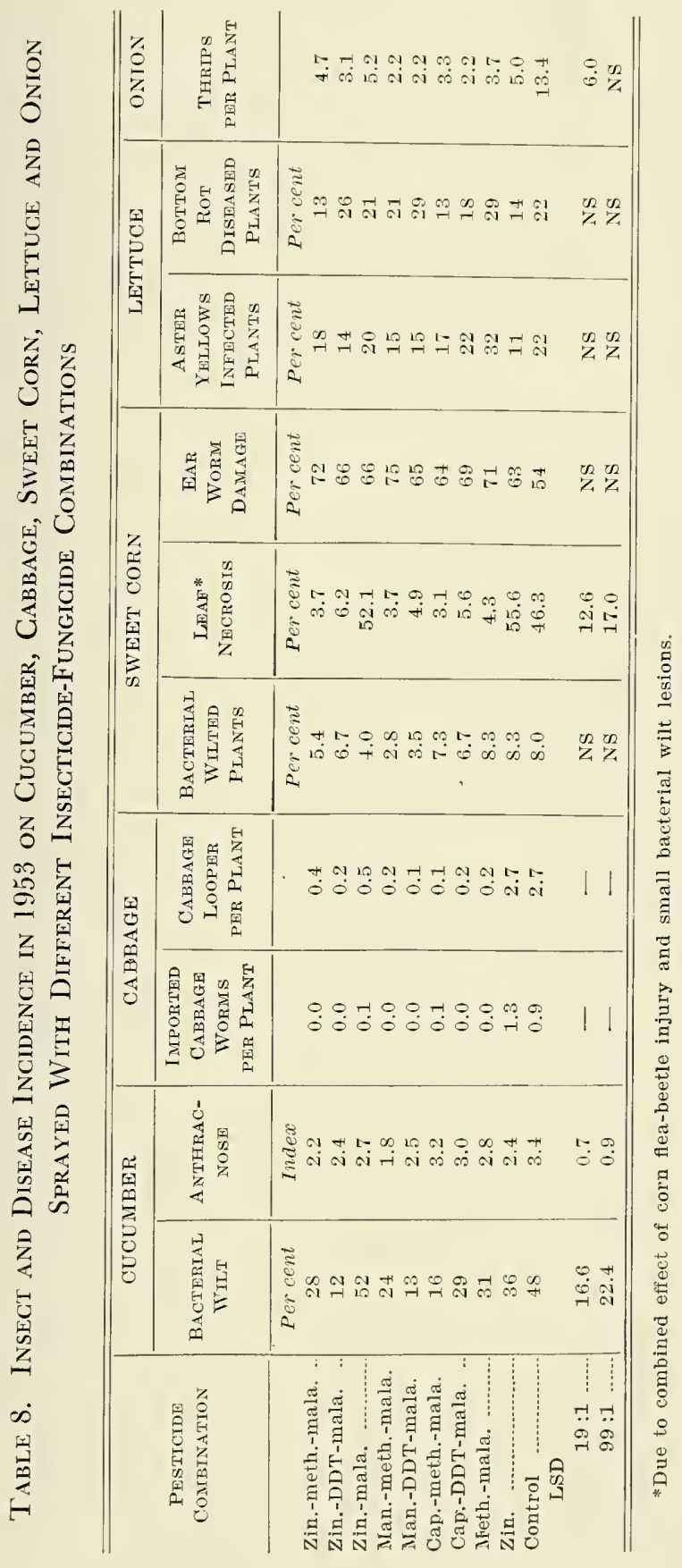




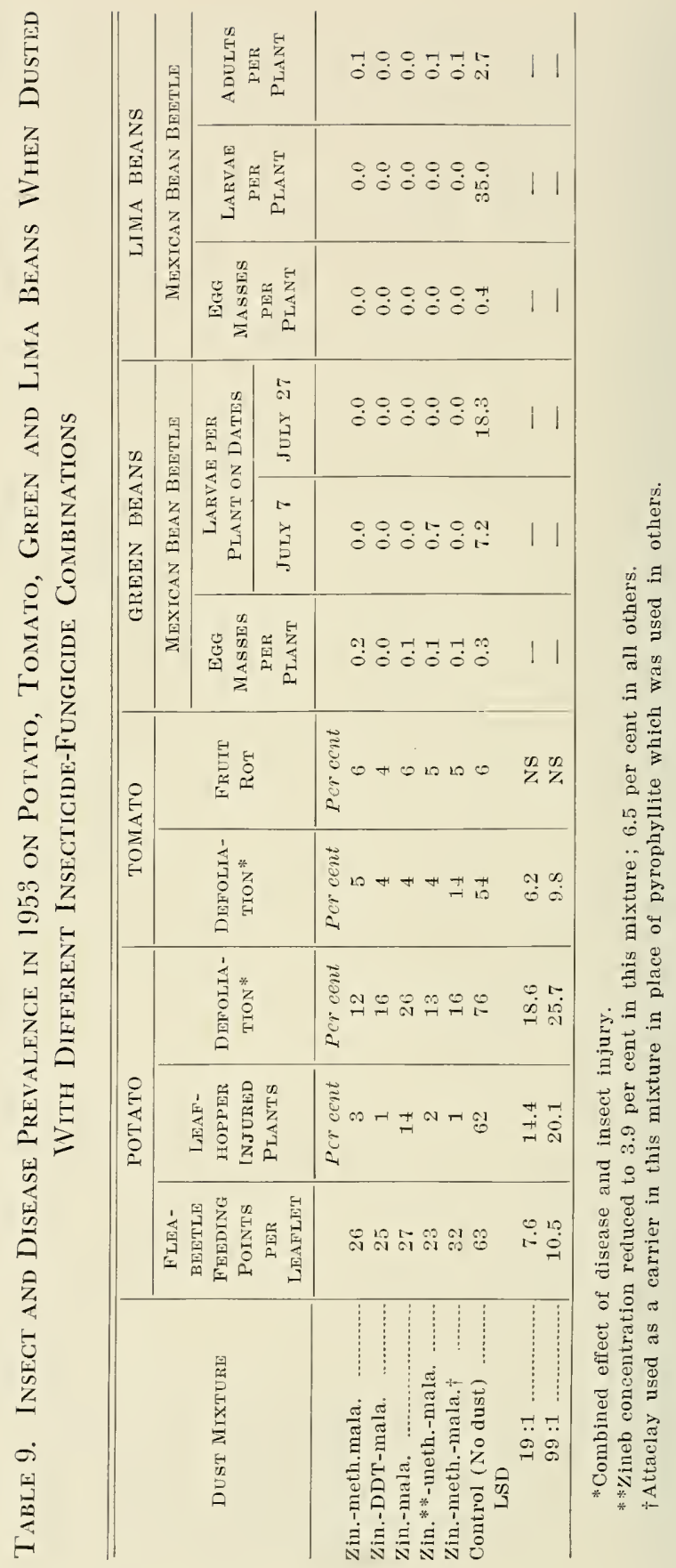




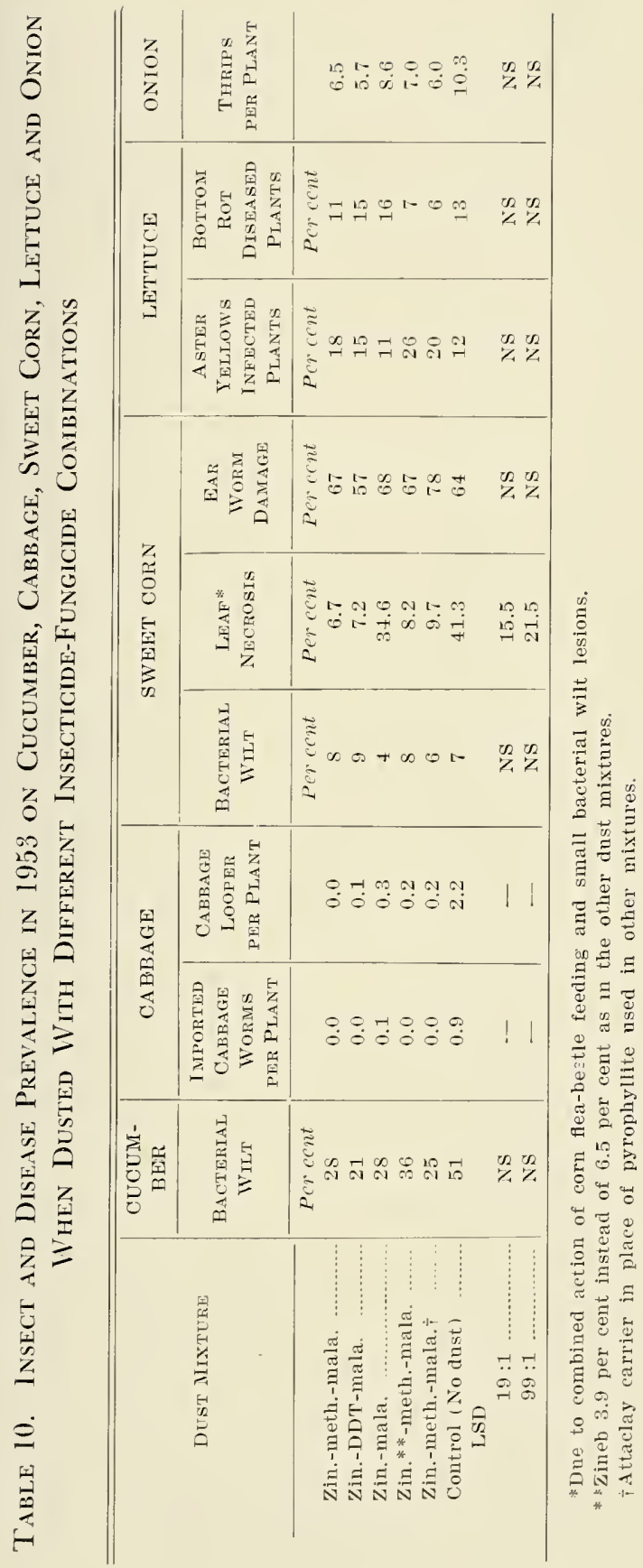




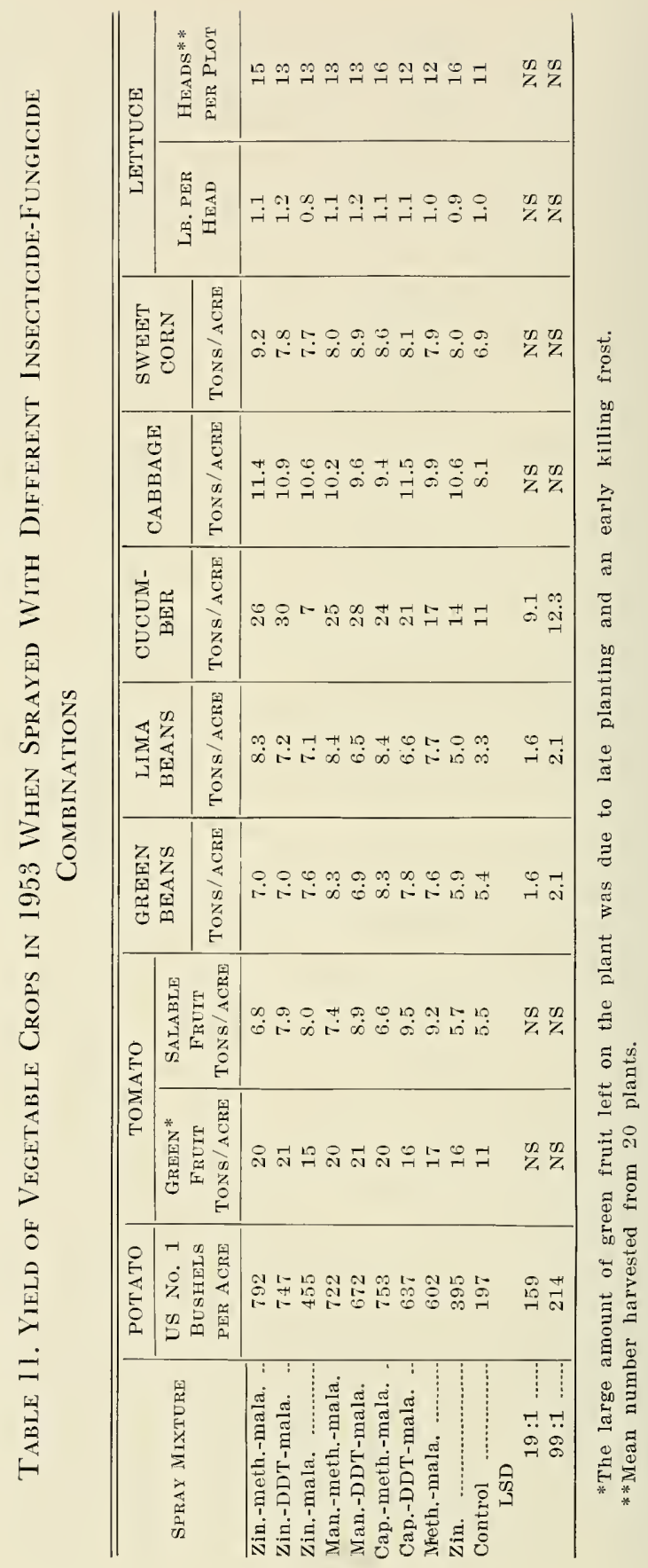




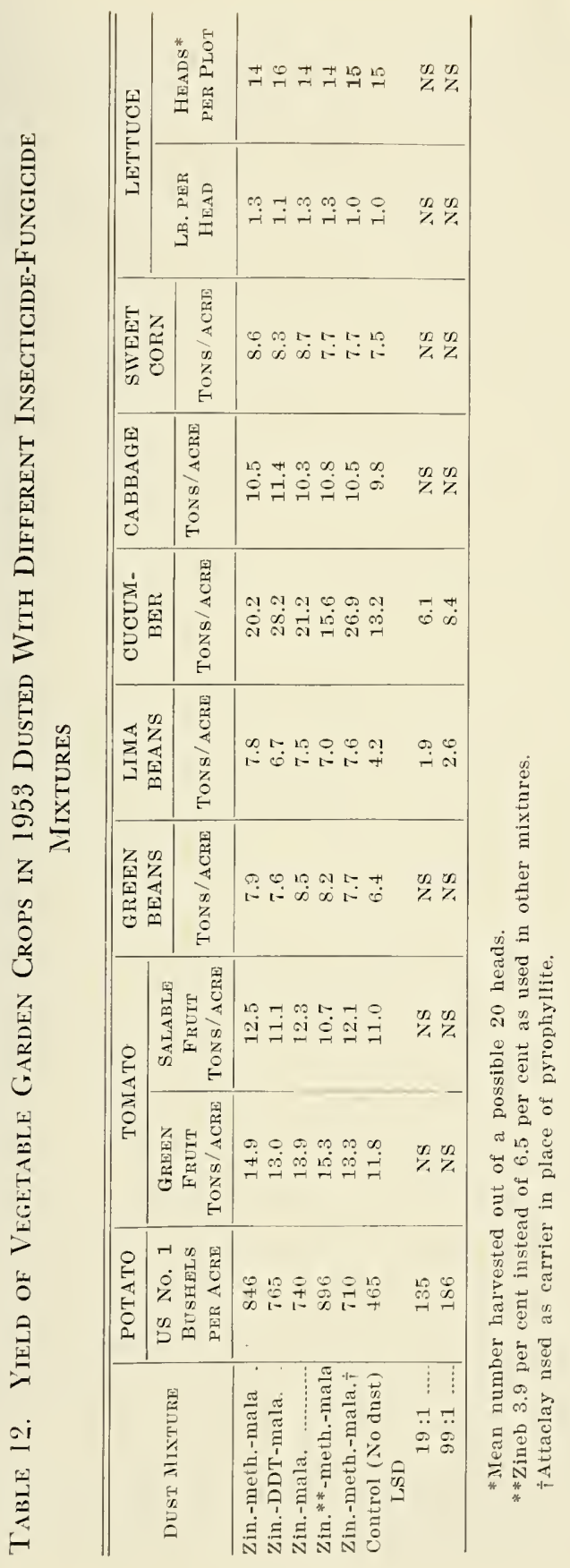


in numbers sufficient to warrant population counts or the evaluation of feeding damage. Early blight was responsible for most of the damage, although there was some late blight present. There were no significant differences between the dust or spray mixtures with respect to fruit rot and total yield. The combinations containing either zineb or maneb gave the best control of defoliation by the early blight fungus.

Green Beans and Lima Beans-Green and lima bean plants were damaged mainly by Mexican bean beetles. All spray and dust mixtures containing malathion gave excellent control of this pest. As the population counts show, Mexican bean beetles were abundant only on plots that were sprayed with zineb only and on the control plots that received no treatment. None of the three different fungicides had any apparent effect on yields. There was a slight depression in yield from plots treated with combinations containing DDT. Since there was no obvious difference in insect control between mixtures containing DDT and those containing methoxychlor, it is possible that DDT is slightly injurious to bean plants. No evidence of phytotoxicity could be seen, however, other than the lower yield.

Cucumber-The spotted and striped cucumber beetles, the associated bacterial wilt, and anthracnose were the principal pests on cucumber. In general, bacterial wilt control was best on plots sprayed or dusted with mixtures containing DDT. Malathion gave poor control of cucumber beetles and a corresponding poor control of wilt. There was little difference between the three fungicides in degree of bacterial wilt control. It should be noted, however, that the presence of a fungicide in the mixtures, in most cases, gave a slight reduction in the incidence of bacterial wilt when compared with that present in the control plots. Plots sprayed or dusted with the zineb-DDT-malathion mixture produced the highest yields and best control of bacterial wilt and cucumber beetles. Incidence of anthracnose was less in plots sprayed with mixtures containing either zineb or maneb; maneb apparently controlled the disease a little more effectively than zineb.

Cabbage-The imported cabbage worm and the cabbage looper were the only pests that damaged cabbage plants. They were effectively controlled on all spray or dust plots except the controls and those receiving zineb alone. Even though the yield showed no significant difference between treatments, the heads harvested from the control plots and those receiving zineb alone were severely clamagd by the feeding of these insects.

Sweet corn-The corn flea beetle and corn earworm were responsible for most of the damage to sweet corn. Although the bacterial wilt resistant variety, Golden Cross Bantam, was used in these experiments, 
some wilt developed. Most of the damage occurred as small leaf lesions that developed around flea beetle feeding wounds. There was no significant difference between treatments in control of the wilt phase of the disease which developed on some young corn seedlings. Spray or dust mixtures containing either methoxychlor or DDT effectively controlled leaf necrosis due to the combined action of flea-beetle feeding and bacterial wilt. Leaf necrosis was not controlled by the zineb-malathion mixture or by zineb alone. Thus the fungicides had no effect upon the severity of the leaf necrosis. No treatment designed specifically to control the corn ear worm was included in these experiments. Heavy rains prevented applications of pesticides during the week that corn was in silk. Even though there were routine weekly applications of spray or dust materials at other times, no control was obtained. This confirms conclusions of other workers that special applications during the silking period are needed for best control of this pest. Although the highest yield was obtained from the zineb-methoxychlor-malathion mixture, the difference between this yield and that from the control plot was not significant.

Head Lettuce-Aster yellows and bottom rot (Pellicularia filamentosa) were responsible for most of the damage to head lettuce. The percentage of plants infected with aster yellows was interpreted as being directly correlated with the incidence of the six-spotted leafhopper, Macrosteles divisus (Uhl.). There were no significant differences among the different spray or dust combinations in either pest control or crop yield.

Onion-The only pest causing damage to onions in 1953 was the onion thrips, Thrips tabaci Lind. The onion sets were planted a month late for the Tygart Valley area. Because of this and early high temperatures, irregular stands and poor growth resulted. Consequently, no attempt was made to obtain onion yields, but the plants were left for the purpose of evaluating thrips control. The data show that this insect was controlled by spray or dust mixtures containing either DDT or methoxychlor with perhaps slightly better results from DDT. Malithion gave little or no control; however, zineb apparently had some repellant action.

Summary of the 1953 results-To obtain a summary of the 1953 performance of the different spray and dust mixtures on the nine vegetable crops, the different pesticide combinations were again ranked from 1 to 4 . The ranks of the spray mixtures are summarized in Table 13, and those of the dust mixtures in Table 14. The spray data slow that the zineb-methoxychlor-malathion, zineb-DDT-malathion, mancbmethoxychlor-malathion, and maneb-DDT-malathion mixtures gave 

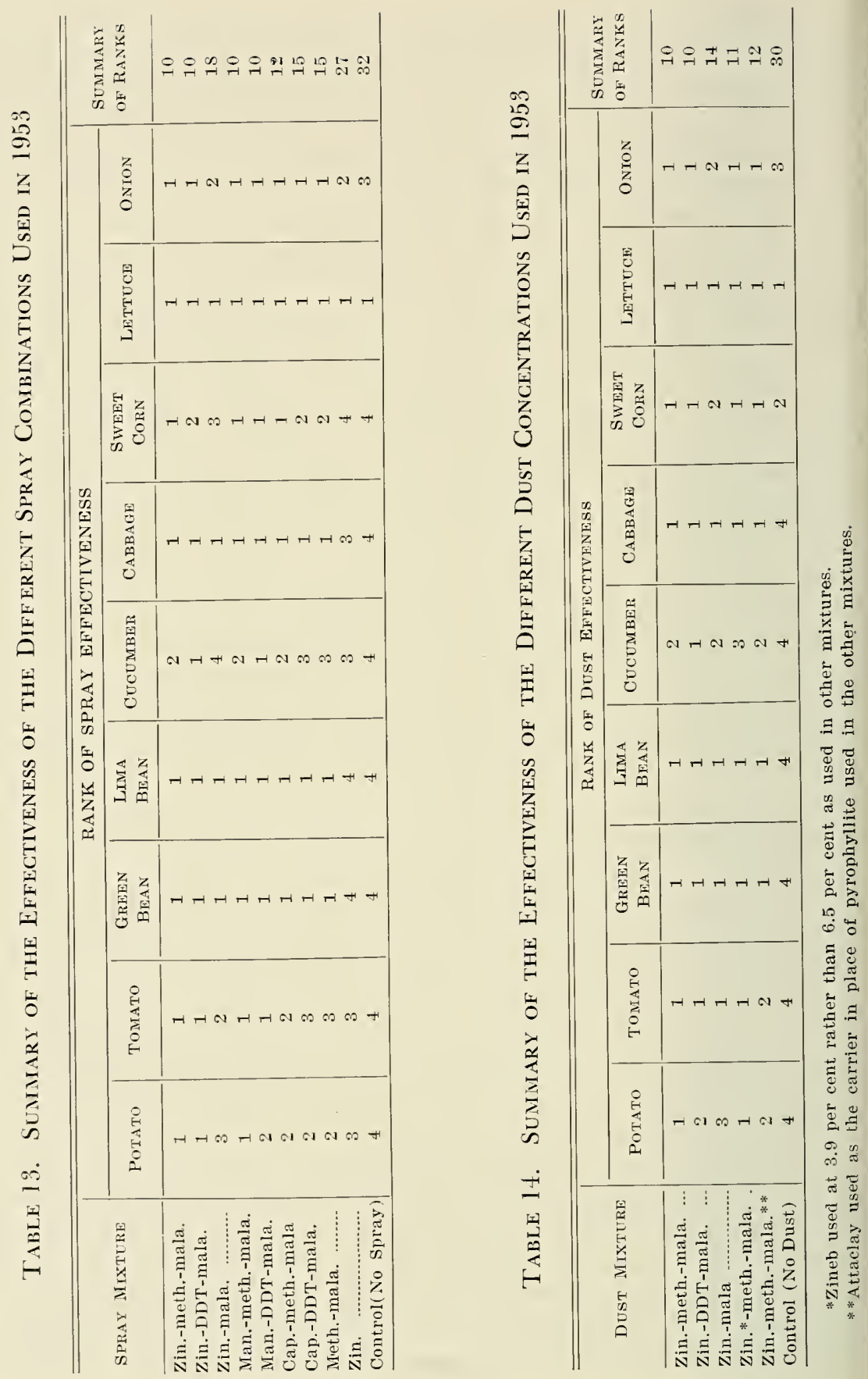
best general control. The dust data also show that the zineb-methoxychlor-malathion and the zincl-DDT-malathion mixtures were most effective in pest control. The mixture with malathion as the only insecticide was inferior because of inadequate control of flea-beetles, leafhoppers, and cucumber beetles. The mixtures containing captan were inferior due to their inadequate control of early blight and cucumber anthracnose.

\section{Discussion}

In general, the early parts of the 1952 and 1953 growing seasons, with respect to moisture and temperature, were normal for the region. From the middle to the end of the growing season climatic conditions were hot and dry both years. Early in the growing season of 1952, aphids, Brevicoryne brassicne (Linnc.) and Rhopalosiphum pseudobrassicae (Davis), began to appear on cabbage, beans, and potato plants. These forms disappeared with the advent of the hot, dry weather. Potato flea beetles were observed early in the season on tomatoes, but they caused little damage. Tomato hornworm, Protoparce quinquemaculata (Haw.), and tomato fruit worm, Heliothus armigera (Hbn.), were present in small numbers on tomatoes. They caused no appreciable damage. The cabbage looper, Trichoplusia ni (Hbn.), was present on cabbage plants, but was much less numerous than the imported cabbage worm. The harlequin bug, Murgantia histronica (Hahn), was scarce on cabbage.

Early in June, 1953, the Colorado potato beetle, Leptinotarsa decimlineata (Say), was present in small numbers on potato plants, but it was never numerous enough to justify population counts. The spotted cucumber beetles fed on potato leaves before cucumber foliage was available; this feeding period was brief and little damage resulted from it. In the bean plots, particularly green beans, several species of leafhoppers, principally Empoasca fabae (Harris), were internittently prevalent and there was evidence of their feeding, though the damage was not sufficient to warrant evaluation. Early in the growing season there was some damage to young head lettuce plants caused by onion thrips, aphids, Myzus persicae (Sulzer), the pale-striped flea beetle, Systenn blanda Melsh., and the meadow spittle bug, Philaneus leucophlhalmus (L.), but these insects disappeared as soon as control opcrations were started. In September, after control operations were discontinued, large populations of the two-spotted mite, Tetranychus bimaculatus. Harvey, appeared on lima bean and cucumber foliage. 
The data from the 1952 tests show that certain insecticides were rather specific in their action in controlling certain insects. DDT gave better control of the imported cabbage worm and of the cucumber beetles than did any of the other insecticides. Rotenone controlled the Mexican bean beetle better than did methoxychlor and malathion. The methoxychlor-malathion mixture gave control almost equal to that of rotenone. Malathion and rotenone gave the best aphid control. There was no apparent evidence of toxicity to plants from any of the spray mixtures, although Cullinan (1) observed that DDT will retard growth of certain plants without causing other obvious symptoms. The summary of the 1-to-4 ranks of the 1952 insecticide treatments presented in Table 7 show that it is difficult to formulate a general-purpose pesticide that will give best control for all pests concerned. The data indicate, however, that it is possible to formulate a pesticide mixture that will give adequate control of most of those garden pests that can be controlled by spraying or clusting the foliage.

As a result of the 1952 spray trials, the zineb-methoxychlor-malathion and the zineb-DDT-malathion combinations were selected as basic formulations for further studies towards the development of an improved general-purpose pesticide mixture. Both spray and dust trials were conducted in 1953. The dust trials were necessary to determine if the pesticides were effective in dust form and to learn about the effect of the diluent and reduced zineb concentration on performance of the dust mixtures. The 1953 spray trials were designed to continue the study of the performance of the zineb-methoxychlor-malathion and zineb-DDT-malathion mixtures and to compare the effectiveness of other fungicicles with that of zineb. The 1953 clata presented in the preceding tables also show that certain pesitcides are specific in pest control. For instance, DDT gave better control of cucumber beetles and resultant bacterial wilt of cucumber, than did methoxychlor. It can also be seen that malathion gave the best control of the Mexican bean beetle, but was relatively ineffective in the control of flea beetles and leafhoppers. Although methoxychlor did not control the imported cabbage worm in 1952 as well as DDT, no difference in control by mixtures containing these two insecticides could be seen in 1953. The 25 per cent wettable DDT powder used in 1952 possibly gave a greater degree of wetting than did the 50 per cent methoxychlor powder. A wetting agent was used in all of the 1953 spray tests. There was comparable effectiveness in disease control by the fungicides zineb and maneb; captan proved inferior to either of these in potato and tomato early blight and cucumber anthracnose control.

Aphids and mites did not build up in sufficient numbers to warrant population counts in 1953. The 1952 data, however, show that mala- 
thion gave excellent control of aphids on tomatoes and cucumbers and fair control of mites on green beans and cucumber. It was observed in 1952 that it was difficult to secure good coverage on the underneath surface of leaves with the single-nozzle hand gun. This may account for limited control of mites during that year. Much better coverage was obtained in 1953 when a three-nozzle boom was used and a wetting agent added to the spray mixture. Also, the concentration of malathion was increased from 2 pounds to 2.5 pounds per hundred gallons. The rapid increase in mite population in September on lima bean foliage after spray applications were discontinued suggests that mites were effectively controlled by malathion. The lima bean plants not sprayed or clusted with malathion were so severely damaged by Mexican bean beetles that it was impossible to determine if mites were previously present.

Although the pesticides show some specificity in pest control, the 1953 summary data in Tables 13 and 14 confirm the 1952 results in that it is possible to formulate insecticide-fungicide combinations that will give good control of all the major foliage pests encountered in a vegetable garden. The data reported here show that the zineb-methoxychlor-malathion, zineb-DDT-malathion, maneb-methoxychlor-malathion, or maneb-DDT-malathion combinations will provide good control. Since there is still some question as to the status of DDT in regard to plant and human toxicity, and since maneb, a relatively new fungicide, is no more =ffective than zineb in disease control and still considerably more expenive, it is concluded that the zineb-methoxychlor-malathion combination vould be the most suitable one for a general-purpose pesticide for the lome gardener.

The results from the dust trials show that the zineb-methoxychlornalathion combination is also effective when formulated in a dust mixure. They also show that the 3.9 per cent concentration of zineb was ust as effective in early blight control as was the 6.5 per cent preparation. The weaker zineb concentration controlled late blight, but the disease vas of minor importance in 1953. There is the possibility that some of the ingredients of the dust mixture may lose strength after prolonged torage, but no conclusive data have been obtained. The dust mixtures repared at the beginning of the 1953 growing season were still eflcctive it the end of the season. Further experiments on the effect of storage in fungicidal and insecticidal effectiveness of the mixed dusts are in jrogress.

On the basis of tests conducted in 1950, Gallegly and Leach ecommended that a mixture of zineb and methoxychlor be used for ;eneral-purpose garden pest control. It was noted, however, that this nixture would not control aphids, mites and adult Mexican bean beetes. 
It is evident from the results reported for the 1952 and 1953 experiments that malathion, in addition to giving aphid and mite control, also improves Mexican bean beetle control. It is concluded therefore that either the spray mixture number 1 (zineb-methoxychlor-malathion given in Table 2 or the dust mixture number 4 (zineb-methoxychlor malathion) given in Table 3, will prove to be satisfactory as a general purpose pesticide for the home gardener.

\section{Summary}

To determine the possibility of developing an improved general purpose spray or dust for use in the home garden, various vegetable crops were treated with different insecticide-fungicide combinations ir 1952 and 1953. During the 1952 tests, potato, tomato, green bean, cu cumber, and cabbage were sprayed with eight different combinations o zineb with methoxychlor, DDT, rotenone, and malathion. Since the 195: experiments were designed to determine the best insecticide combina tion, the fungicide zineb was used in all spray treatments. This year' data showed that the zineb-methoxychlor-malathion and zineb-DDT malathion combinations were best for general-purpose control of potat flea beetles, leafhoppers, imported cabbage worms, Mexican bean beetles apliids, cucumber beetles, and mites.

The latter mixtures served as a basis of comparison for furthe experiments in 1953 when nine different vegetable crops, including lim beans, sweet corn, head lettuce, and enions, in addition to the five crop listed above, were sprayed and dusted with various mixtures of th fungicides zineb, maneb, and captan, and the insecticides methoxychlor DDT, and malathion. The 1953 results show that the zineb-methoxy chlor-malathion, zineb-DDT-malathion, maneb-methoxychlor-mali thion, and maneb-DDT-malathion mixtures gave best general-purpos. control of tomato and potato early and late blight and cucumber ar thracnose. Insects controlled by these mixtures were the potato fle beetle, potato leafhopper, onion thrips, six-spotted leafhopper, importe. cabbage worm, cabbage looper, Mexican bean beetle, corn flea beetle and spotted and striped cucumber beetles. Other insects, incidenta early in the season, which disappeared as soon as control operations wer initiated, included the meadow spittlebug, miscellaneous leafhopper Colorado potato beetle, and the pale-striped flea beetle.

After considering pest control and crop yield data for the past tw years, the cost of materials and the factors of toxicity, the zineb-methox: 
chlor-malathion combination is recommended as a satisfactory generalpurpose pesticide for the home garden.

\section{Literature Cited}

1. Cullinan, E. P., "Some New Insecticides-Their Effect on Plants and Soils," Jour. Econ. Entomology, Vol. 43 ((1949), pp. 387-391.

2. Gallegly, M. E., and Leach, J. G., Simplification of Garden-Pest Control, W.Va, Agr. Exp. Sta. Bul. 348, 1951.

3. Horsfall, J. G., and Barratt, R. W., "An Improved Grading System for Measuring Plant Diseases," Abstract, Phytopathology, Vol. 35 (1945), p. 655.

4. Leach, J. G., and Yount, W. L., "The Practicability of an All-Purpose Fungicide and Insecticide Dust for the Home Garden," Proc. IV.I Ia. Acad. Sci. Vol. 20 (1948), pp. $48-53$.

5. Turner, Neely, and Woodruff, Nancy, "Chlorinated Insecticides for Control of the Potato Flea Beetle," Journ. Econ. Entomology, Vol. 41 (1948), pp. 328-329. 
